\title{
Readiness to Implement Inclusive Edu- cation in Muhammadiyah Elementary Schools of Yogyakarta
}

\author{
DOI 10.18196/AlIJS.2020.0124.263-287
}

\section{RATNA SARI, ${ }^{1}$ M. NURUL IKHSAN SALEH ${ }^{2}$ \\ Fakultas Agama Islam, Universitas Muhammadiyah Yogyakarta ${ }^{1}$ Fakultas IImu Agama Islam, Universitas Islam Indonesia ${ }^{2}$ \\ Correspondence E-mail: ratna.sari@umy.ac.id ${ }^{1}$}

\begin{abstract}
This research aims to analyse the readiness of Muhammadiyah elementary schools in implementing inclusive education in the schools. Through a case study methodology with a purposive sampling technique, this research investigates the readiness of four Muhammadiyah elementary schools. The data were collected by an in-depth interview and observation and would be analyzed by thematic analysis method. This research provides worthy indicators of school readiness in executing inclusive education. This study indicates that two out of the four Muhammadiyah elementary schools observed, have not reached the required level of readiness to implement inclusive schools based on the indicators of the school readiness, whereas the other two schools are more prepared to fully run the inclusive education program. This study enhances elementary schools to implement inclusive education by meeting five required indicators: 1) Perception of school stakeholders; 2) Curriculum and teaching and learning activities; 3) Educational staffs; 4) Facilities, infrastructure, and funding; 5) Relationship between community and school. The implementation of inclusive education in elementary schools under the Muhammadiyah institution as one of the biggest Islamic organizations in Indonesia would build a positive perception for all teachers, students' parents, and school communities.

Keywords: School Readiness, Inclusive Education, Muhammadiyah elementary school
\end{abstract}

\footnotetext{
ABSTRAK

Penelitian ini bertujuan untuk menganalisis kesiapan Sekolah Dasar Muhammadiyah dalam melaksanakan pendidikan inklusi. Melalui metode studi kasus, dengan teknik purposive sampling, penelitian ini menyelidiki kesiapan empat Sekolah Dasar Muhammadiyah. Pengumpulan data dilakukan dengan wawancara mendalam dan observasi serta dianalisis dengan metode analisis tematik. Penelitian ini memberikan
} 
indikator kesiapan sekolah dalam melaksanakan pendidikan inklusif. Hasil penelitian ini menunjukkan bahwa dua dari empat SD Muhammadiyah yang diamati belum mencapai tingkat kesiapan yang disyaratkan untuk melaksanakan sekolah inklusi berdasarkan indikator kesiapan sekolah, sedangkan dua sekolah lainnya lebih siap menjalankan program pendidikan inklusif. Studi ini mendorong sekolah dasar untuk melaksanakan pendidikan inklusif dengan memenuhi lima indikator yang dibutuhkan: 1) Persepsi pemangku kepentingan sekolah; 2) Kurikulum dan kegiatan belajar mengajar; 3) Tenaga kependidikan; 4) Sarana, prasarana, dan pendanaan; 5) Hubungan antara komunitas dan sekolah. Penyelenggaraan pendidikan inklusi di sekolah dasar di bawah institusi Muhammadiyah sebagai salah satu organisasi Islam terbesar di Indonesia akan membangun persepsi positif bagi seluruh guru, orang tua siswa, dan komunitas sekolah.

Kata kunci: Kesiapan sekolah, Pendidikan inklusi, Sekolah Dasar Muhammadiyah

\section{INTRODUCTION}

The growing diversity in today's classroom not only covers students' learning abilities, but also encompasses other aspects such as race, ethnicity, religion, physical condition, students' need, and others. ${ }^{1}$ The diversity of students is not a barrier in achieving quality education, as stated in the 1945 Constitution (UUD 1945) article 31 number 1, that every citizen has the right to education. The opening of the Salamanca Declaration states that more than 300 participants from 92 countries and 25 international organizations gathered in the city of Salamanca, Spain in June 1994 to discuss the fundamental policy change needed to promote an inclusive education approach, that is education that allows schools to serve all children, especially children with special needs. ${ }^{2}$ This declaration also highlights the need for joint concrete efforts in realizing "Schools for all", that is schools that accommodate everyone, celebrate differences, support learning, and respond to individual differences. $^{3}$

Lately, schools in Indonesia are generally divided into two categories: regular schools and schools for students with disabilities or often referred to as Special Schools (Sekolah Luar Biasa/SLB). There has been a widely held assumption shared by the communities that children who are physically and mentally healthy shall go to regular schools, while the SLB is provided for students with special needs due to physical and psychological disabilities. Likewise, based on the shared community's understanding, inclusive education is often assumed as a program intended for children with disabilities.

The Salamanca Declaration is a milestone in the implementation of inclusive education in the world. ${ }^{4}$ The inclusive education movement is a response 
to the separation in the education of children with special needs into separate educational institutions. ${ }^{5}$ The Indonesian Government through the Minister of National Education Regulation (PERMENDIKNAS) No. 70 of 2009 states that inclusive education is defined as a system of education that provides opportunities for all students who have physical and psychological limitations, and potential intelligence and special talents to participate in education or learning in a shared educational environment with students in general. ${ }^{6}$ This is in line with the second point of the Salamanca Declaration that every person with disabilities has the right to express their desire to gain access to education, while parents have the right to consult on the form of education that best suits the needs, circumstances and aspirations of their children. ${ }^{7}$

As explained in PERMENDIKNAS Number 70 of 2009, inclusive schools should provide the equal learning opportunities for all their students, including children with special needs who study at the school. ${ }^{8}$ To this end, inclusive school should prepare several valuable components such as human resources at schools, especially teachers. The teacher is a figure who plays a central role in organizing the learning activity so that the learning process can run smoothly according to the needs of each student. Hence, teachers are required to master four teacher competencies; pedagogic competence, professional competence, personality competence, and social competence to enable them to plan, organize and manage the learning process in inclusive schools. In addition, supporting facilities are also a valuable component in the implementation of inclusive schools. ${ }^{9}$ Generally, regular schools only provide regular facilities for regular students. Meanwhile, students with special needs and physical disabilities need special facilities to participate in learning activities to the fullest. Thus, inclusive schools are required to support the needs of all students, including those with special needs.

Furthermore, the readiness of human resources is a crucial factor in implementing inclusive learning. School members such as employees and students' parents should be ready in the implementation of inclusive schools. ${ }^{10}$ The preliminary research shows that three of the students' parents has a negative perception of the implementation of inclusive schools. Parents of regular students are reluctant to have their children attend school with children of physical and psychological limitations. The parents of regular students assume that normal children would encounter obstacles when they study in the same classroom with students having the special needs. Meanwhile, three teachers from different schools considered that inclusive class teaching com- 
petencies were only possessed by teachers with special education background. Therefore, teachers with other educational backgrounds, such as teacher training program background were considered to lack competence in holding inclusive education.

The aforementioned background highlights the need for the implementation of inclusive education in Indonesia. This implementation is expected to provide broader learning opportunities for children who have different physical and psychological conditions. Therefore, it is vital to investigate the school readiness in implementing inclusive education.

Despite some obstacles in the implementation of the development of inclusive education in Indonesia, many Yogyakarta elementary schools have held inclusive education program. ${ }^{11}$ However, it is necessary to study the readiness of these schools to achieve the existing standards and criteria in implementing inclusive schools in Yogyakarta. There are five essentials aspects to assess the school readiness: perception of school stakeholders, curriculum, teaching and learning activities, educational staffs, facilities, infrastructure and funding, relationship between community and school. This study specifically examined the readiness of Muhammadiyah elementary schools in implementing inclusive education for all students. Muhammadiyah Elementary Schools have contributed a lot in advancing education in Indonesia. In particular, Muhammadiyah Elementary Schools in Yogyakarta have implemented inclusive schools' program. Hence, this study was conducted in Yogyakarta to provide an overview to other Muhammadiyah elementary schools in Indonesia to prepare for the implementation of inclusive education.

\section{LITERATURE REVIEW}

Cambridge Dictionary defines "inclusive" as to where an inclusive group or organization tries to include many different types of people and treat them fairly. ${ }^{12}$ Belanger mentions that 'academic inclusion' refers to the full-time integration of all students regardless of each student's difficulties which take place in a regular class according to their age and is located in a school close to where students live. ${ }^{13}$ Moreover, Eripek explains that inclusive education is an implementation where students with special needs and students with regular development have equal education. ${ }^{14}$ The definitions above are in line with PERMENDIKNAS Number 70 of 2009 article 1 that states that inclusive education is an educational system implementation that provides opportunities for all students who have abnormalities and have the potential of intelligence 
and/or special talents to participate in education or learning in one educational environment together with students in general. ${ }^{15}$

From the explanation above, it can be concluded that inclusive schools are regular schools that provide the equal learning opportunities for students who have different physical and psychological background as well as students with special needs and students who have special talents to attend the learning process with normal children or regular students. Inclusive schools accept all types of children in school, including children with special needs who have diverse disability backgrounds.

There are several models of education for children with special needs in inclusive schools, ${ }^{16}$ regular class (full inclusion), regular class with cluster, regular class with pull out, regular class with cluster and pull out, special class with various integration, and full special class. Inclusive schools facilitate the diversity that exists in students. The diversity of students includes:

a. Intelligence

Intelligence is one of the general and potential human abilities. Intelligence is influenced by certain factors namely: innate factors, environment, distinctive interests and character, maturity, and freedom. Intelligence includes not only thinking intelligence but also emotional and spiritual intelligence.

b. Learning Style

Learning style is a process of behaviour, appreciation, and a tendency for someone to learn something in a separate way that is different from each other. ${ }^{17}$ Learning styles greatly influence the learning process of students. The right learning style would increase the success of students in learning. Kanar classifies learning styles related to physiological factors into 3 parts, namely; visual, auditory, and kinaesthetic. ${ }^{18}$

c. Personality

Funder states that personality refers to patterns of individual characteristic of thought, emotion, and behaviour, along with psychological mechanism, both hidden and not hidden patterns. ${ }^{19}$ Personality is a characteristic of someone in facing their lives, Empirically, each student has his or her own unique personality that distinguishes him or her from other students. ${ }^{20}$

d. Culture and Ethnicity

Identity and culture are the two basic components of ethnicity. ${ }^{21}$ According to the Cambridge dictionary, culture is the way of life, especially the 
general customs and beliefs, of a particular group of people at a particular time. ${ }^{22}$ Moreover, ethnic is related to a particular race of people. ${ }^{23}$ Thus, culture is a pattern of behavior, beliefs and all products produced by certain groups of people in their homes or results from the inheritance of generations. Every individual has a different cultural and ethnic background from one to another, which affects his or her daily lives. A culture is a form of diversity that is brought and/or inherited by parents and people who live with an individual. Inclusion schools should also implement multicultural education by organizing education for all students with different ethnicities, cultures, and religions.

e. Socio-economic status

Each student has a different social and economic background from one another, which is usually influenced by family background and/or parents. Socio-economic status grouping often has a negative influence on students. Students of the lower middle class often feel inferior and lower level of confidence than to students of the upper middle class. Conversely, grouping students as middle to upper economic class can lead to superior attitudes in students. According to House and Galobardes, socio-economic status is a measure of the combined economic and social status of individuals. ${ }^{24}$ Social status not only leads to grouping based on economic characteristics but also relates to influence, position, and others. The economic status is a way to label group people based on economic characteristics. In sociology, socio-economic status is measured using a composite measure of education, income, and employment or several variations of the three indicators. ${ }^{25}$ Inclusive schools need to design a curriculum by considering equality among all students and respecting students' social diversity, including students' socio-economic status. ${ }^{26}$

f. Language

The variety of languages used by each student can be influenced by several things, namely; ethnicity, culture, and family background. Language is one of the factors that can influence students in understanding the learning that takes place in the classroom. ${ }^{27}$

g. Gender

The process of students' understanding and learning is influenced by certain factors, such as student motivation, students' daily language, age, and gender, and socioeconomic status. ${ }^{28} \mathrm{It}$ is necessary to apply equality in learning to all sexes, in order to get equal rights in learning. 
UNESCO explained that inclusive schools accept all children regardless of their abilities, disabilities, gender, HIV status and health, as well as their socioeconomic, ethnic, religious or language background. ${ }^{29}$ Therefore, inclusive school is a place for everyone, with diverse backgrounds and conditions. Learning opportunities are given to all, including students who have severe physical and health problems, such as HIV. This is in line with PERMENDIKNAS Law No. 70 of 2009 which mentions that there are 13 categories of children with special needs that will be accepted in inclusive education, such as: the blind, deaf, speech impaired, mental retardation, physically disabled, unsociable, problem learner, slow learner, autism, motoric disorder, being a victim of drug abuse, drugs, and other addictive substances, having other abnormalities, and having double handicaps. ${ }^{30}$

More resources become increasingly available for improving access to education in middle-income countries. Hence, children without disabilities increasingly attend school, while the condition of children with disabilities increases more slowly. ${ }^{31}$ Likewise in Indonesia, inclusive education in Indonesia has been initiated by the government since 2002. ${ }^{32}$ Inclusive education promotes diversity in a learning environment. The most prominent diversity is the cognitive abilities of students. In an inclusive school, all students with different levels of intelligence can achieve learning according to their needs. In other words, not only students with average or regular intelligence are accepted in school, but also are students with intelligence above and below the average who should obtain their learning rights. This is as stated in Article 31 of the 1945 Constitution that every Indonesian has the right to education.

An inclusive school is a school model that is expected to accommodate education for all children. On August 11, 2004, in Bandung-West Java Province, there was an official declaration of "Indonesia towards Inclusive Education", which is expected to motivate regular schools to provide education for all children with special needs, including children with mental retardation. ${ }^{33}$ The inclusive education system is developed to eliminate discrimination between children with special needs and people in the surrounding environment. ${ }^{34}$ This is based on the fact that negative stigma is often given to students with different physical deformities, mental disorders, races and religions. ${ }^{35}$ Discrimination experienced by students of special needs is both in the provision of educational services and the availability of learning facilities. Schools that organize inclusive education need to create the learning atmosphere by referring to one of the goals of inclusive education to respect 
diversity and reduce discrimination for all students. ${ }^{36}$ In addition, schools and teachers also need to make adjustments to the curriculum and learning process to the abilities and needs of exceptional children. ${ }^{37}$ Adjustments to the curriculum and learning process should meet the needs of all students. Therefore, children with special needs also have the equal right to study and receive the teaching materials from teachers in the school.

Muhammadiyah as a large Islamic organization in Indonesia has been working in education since in its establishment in 1912. According to Muhammadiyah Business Charity (Amal Usaha Muhammadiyah/ AUM) database, there are 2.604 Muhammadiyah elementary schools throughout Indonesia. ${ }^{38}$ In Yogyakarta, there are 10 Muhammadiyah elementary schools that administer inclusive education based on the Decree of the Head of the Yogyakarta City Education Office on the determination of School of Inclusive Education Provider (Sekolah Penyelenggara Pendidikan Inklusi/ SPPI). ${ }^{39}$ SPPI is a regular school appointed by the Yogyakarta City Education Office to organize inclusive education by accepting all students, both regular students and students with special needs. The implementation of inclusive schools aims to eliminate the rejection of students with special needs who want to study in regular schools in Yogyakarta. It further eases the community to access education from the basic level to the higher level of education.

Mangunsong states that there are 8 components to prepare for the implementation of an inclusive school. ${ }^{40}$ These components are:

a. The change of perspective and the attitude of all school elements in looking at the diversity of students.

b. Reorientation of assessment, teaching methods and classroom management, and environmental adjustments.

c. Redefining the role of the teacher and reallocating human resources.

d. The redefinition of the role of existing extraordinary schools (SLB), whether the schools could gradually begin to function as an extensive source of learning or not.

e. Availability of professional assistance for teachers in the form of reorientation of in-service training and training of teachers, principals and classroom teachers, so that all school members can make a full contribution in realizing inclusive education.

f. Availability of visiting teacher services as needed.

g. Formation, improvement, and development of partnerships between teachers and parents to establish smooth communication related to the devel- 
opment of students learning and other school activities.

h. The flexibility of education system, curriculum and examination system.

A regular school should meet the above components to be categorized as a school that has achieved the readiness level to become an inclusive school. The readiness component in this research is specified in several aspects, namely: school community perceptions, curriculum and teaching, and learning activities, education staff, facilities, infrastructure, funding, and relations between the community and the school.

\section{RESEARCH METHOD}

This study uses a case study methodology. Case studies are a strategy of examination in which the researcher investigates in depth a program, event, activity, or process. ${ }^{41}$ It used a purposive sampling technique to investigate school readiness. Purposive sampling technique is conducted by identifying the purposefully selected sites or individuals for the proposed study. ${ }^{42}$ The participants in this study are stakeholders in Muhammadiyah Elementary School that consist of 5 teachers, 7 parents, and 4 principals. The research location consists of four Muhammadiyah elementary schools; 2 Muhammadiyah elementary schools in Yogyakarta city and 2 Muhammadiyah elementary schools in Sleman regency, Special Region of Yogyakarta. The data were collected using an in-depth interview and observation. The data analysis techniques consist of data reduction, data presentation and verification. ${ }^{43}$ The researcher conducted data validation using triangulation of data sources. Patton mentioned that triangulation refers to the use of multiple methods or data sources in qualitative research to develop a comprehensive understanding of phenomena. ${ }^{44}$ The triangulation method refers to linking different data source: interviews, and observation for a comprehensive understanding of a complex social situation. ${ }^{45}$ In the data analysis, the school names were made anonymous by categorizing the schools in four names: Elementary School $(A)$, Elementary School (B), Elementary School (C), and Elementary School (D).

\section{RESULT AND DISCUSSION}

The result of participants' interview could be seen in table 1.

\section{PERCEPTION OF SCHOOL STAKEHOLDERS}

In some countries, inclusive education is thought of as an approach to serving children with disabilities within general education settings. ${ }^{46}$ This is in 
line with the opinions of all respondents in this study, that inclusive schools are regular schools with 2 categories of students, regular students and students with special needs. The widely held perception is in contrast with Salamanca Statement which states that the special education is a place of learning for children and adolescents who need to rise from learning disabilities or difficulties. ${ }^{47}$ Furthermore, it is explained that schools should accommodate all children regardless of physical, intellectual, social, emotional, language or other conditions. ${ }^{48}$ In conclusion, inclusive education is not only regular school with regular students and students with special needs, but also a school that facilitates the diversity of students as stated in Salamanca Statement.

The principal of the Elementary School (B) stated that accepting special needs children and combining them with the regular students in the classroom would hamper the quality improvement in school because teachers would need to work harder to serve special needs children. Furthermore, the headmaster of the Elementary School (B) argued that accepting inclusion children would prevent the school from providing optimum services. This school also gives reasons that the school have high targets in students' academic and non-academic achievements, so the existence of inclusive students is feared to hamper the learning activities of regular students in the class. Since each class contains 30 to 40 students with one teacher who uses classical methods in delivering the material, the Principal explained that the school would find it difficult to deal with students having the special needs since most of them are slow learners. Moreover, the principal of the Elementary School (A) said that to transform the school to be inclusive school is difficult.

Most of the teacher expressed a negative opinion about inclusive education. ${ }^{49}$ The teacher from Elementary School (B) also stated that it would be difficult to apply the learning system with the moving class method to students with special needs because students would need the help of others at all times to be able to take part in teaching and learning activities. The teacher stated that students with special needs were of slow learners and thus would hinder the achievement of learning objectives for regular students in the class. Teachers from Elementary School (B) expressed similar opinion with the Principal that the large number of students in one class limited the teacher's ability to pay attention to every child in the classroom, especially when there are students with special needs or inclusion children who should receive 
Table 1. Summary of Participants' Statements

\begin{tabular}{|c|c|c|}
\hline Participants & Schools & Statements \\
\hline \multirow[t]{4}{*}{ Principals } & $A$ & $\begin{array}{l}\text { "It is not an easy thing if this school has to be transformed into an } \\
\text { inclusive school, to be honest we are not ready to become an inclusive } \\
\text { school. However, if it is necessary then we will make careful planning to } \\
\text { overcome it." } \\
\text { "Our school does not have facilities and infrastructure such as inclusive } \\
\text { school, we are still using the } 2013 \text { curriculum and do not have experience } \\
\text { in modifying the curriculum for students with special needs." } \\
\text { "All of our class teachers have undergraduate educational backgrounds } \\
\text { and have never attended training to teach in an inclusive school." } \\
\text { "The large fund is needed for implementing inclusive school. Currently, } \\
\text { this school do not have specific funding that can be used for } \\
\text { implementing inclusive schools." }\end{array}$ \\
\hline & B & $\begin{array}{l}\text { "Suppose we accept inclusive children in our school, and they study with } \\
\text { other regular children. In that case, it will hinder the improvement of the } \\
\text { quality in our school because we need much energy to serve children with } \\
\text { inclusion. So, if our school accept inclusive children, then the services we } \\
\text { provide will not be optimal." } \\
\text { "So, our school is not ready to become an inclusive school. We do not } \\
\text { have a special educator who can teach inclusive children. The cost of } \\
\text { inviting special teachers to school is high, and this school is a private } \\
\text { school, so the government does not provide funding for it." } \\
\text { "This school cannot optimally provide support to regular children yet. In } \\
\text { contrast, inclusive children need more support and services than regular } \\
\text { children." }\end{array}$ \\
\hline & C & $\begin{array}{l}\text { "This school is not yet an inclusive school due to limited funds for } \\
\text { facilities and infrastructure. However, this school has several students } \\
\text { with special needs, such as slow learners." } \\
\text { "In making the public school into inclusive school, more funds are needed } \\
\text { to prepare adequate facilities and infrastructure. The teacher must be } \\
\text { patient in teaching children with special needs because they are unique. } \\
\text { They should also be paid more attention to special needs students than } \\
\text { regular students. Even though the facilities and infrastructure are } \\
\text { inadequate, the teacher must keep the spirit in teaching." }\end{array}$ \\
\hline & D & $\begin{array}{l}\text { "This school accepts children with special needs with the categorization } \\
\text { of mental retardation, ADHD, moderate mental retardation, low vision, } \\
\text { and slow learner. For special needs children with physical problems, the } \\
\text { school have not been able to provide adequate facilities. So that special } \\
\text { needs children with physical problems cannot be served well. Facilities } \\
\text { for children with special needs have not been maximally fulfilled, because } \\
\text { there are still many facilities that are not available yet." } \\
\text { "The educational programs available at this school are general education } \\
\text { programs, then additional activities of a religious education, and } \\
\text { education for children with special needs." } \\
\text { "In this school, there are six students with special needs and ten students } \\
\text { who are indicated with special needs. Children with special needs in this } \\
\text { school participate in teaching and learning activities in the same class as } \\
\text { regular children. At certain times the class teacher will provide additional } \\
\text { time as a form of additional learning for children with special needs. This } \\
\text { school has also provided special teachers for children with special needs } \\
\text { to assist them in the learning process." }\end{array}$ \\
\hline
\end{tabular}




\begin{tabular}{|c|c|c|}
\hline Participants & Schools & Statements \\
\hline \multirow[t]{4}{*}{ Teachers } & A & $\begin{array}{l}\text { "Our school is a regular school that uses the } 2013 \text { Curriculum, and all } \\
\text { students are regular children. We do not have any special needs student." } \\
\text { "We do not have facilities for students with special needs." } \\
\text { "I think our school does not need to organize an inclusive school yet." }\end{array}$ \\
\hline & B & $\begin{array}{l}\text { "I feel that I am not ready if our school become an inclusive school } \\
\text { because in this school there are no special teachers for inclusive children. } \\
\text { The teachers who teach in this school are all regular school teachers, so } \\
\text { they do not have the special abilities to deal with inclusive children." } \\
\text { (Teacher 1) } \\
\text { "Our school uses a moving class system. This system will be one of the } \\
\text { obstacles for special need student because they are difficult to adapt. } \\
\text { Special needs student will need a long time to adapt, including moving } \\
\text { from one classroom to another classroom, or from one type of teacher to } \\
\text { another." (Teacher 2) } \\
\text { "There will be many ineffectiveness that will happen to both inclusive and } \\
\text { regular children if there is a student with special needs in this school." } \\
\text { (Teacher 2) }\end{array}$ \\
\hline & $C$ & $\begin{array}{l}\text { "In dealing with students with special needs, it is divided into several } \\
\text { ways; first, by approaching students and inviting students to be involved } \\
\text { in classroom learning. Second, communicating with fellow teachers who } \\
\text { handle students with special needs and parents of students with special } \\
\text { needs. Third, give more time to students with special needs to learn, while } \\
\text { the way to teach them is the same as other regular students. Moreover, } \\
\text { always monitors students' progress." }\end{array}$ \\
\hline & $\mathrm{D}$ & $\begin{array}{l}\text { "The subject matter in this school is the same for regular and special } \\
\text { needs students. However, the achievement indicators of children with } \\
\text { special needs are not the same as indicators of learning achievement of } \\
\text { normal children. Teacher lowering the standard of achievement } \\
\text { indicators for students with special needs by adjusted to the abilities of } \\
\text { students with special needs. At the same time, the studying hours for } \\
\text { students with special needs are the same as for regular students." } \\
\text { "There is training to improve teacher competence and training related to } \\
\text { handling students with special needs which is carried out regularly, twice } \\
\text { every semester. This training usually invites experts from the education } \\
\text { authorities and psychologist." }\end{array}$ \\
\hline \multirow[t]{2}{*}{ Parents } & A & $\begin{array}{l}\text { "Children with special needs cannot study together with regular children, } \\
\text { because they can interfere other regular children in learning at class." }\end{array}$ \\
\hline & B & $\begin{array}{l}\text { "Children with special needs cannot go to the same school as regular } \\
\text { children. The children's portion of learning and comprehension is } \\
\text { different. Moreover, regular children will not even be able to improve their } \\
\text { learning because they have to adjust to inclusive children." (Parent 1) } \\
\text { "Regular children can study with children with special needs, as long as } \\
\text { the school can facilitate the special needs student well. So that in the } \\
\text { teaching and learning process, special needs and regular children can be } \\
\text { equal." (Parent 2) } \\
\text { "In terms of curriculum, teaching staff and school facilities must support } \\
\text { the implementation of inclusive schools, so that special needs children } \\
\text { can experience the same education as other regular children." (Parent 3) }\end{array}$ \\
\hline
\end{tabular}




\begin{tabular}{lll}
\hline Participants & Schools & Statements \\
\hline C & "Children with special needs cannot attend this school because there are \\
& no facilities for children with special needs. In this school, the facilities \\
& are only for regular children."
\end{tabular}

more attention than other students. Furthermore, teacher of Elementary School (A) mentioned that the school does not need to organize the inclusive school.

Parents of a student from Elementary School $(A, B, C)$ stated his disagreement about the school acceptation of students with special needs because it was feared that it would disrupt regular students learning activities. In contrast, the other three parents from Elementary School $(A, D)$ thought that it would not be a problem to accept students with special needs. Parents of two students who agreed on the implementation of inclusive education added that schools should be able to facilitate inclusion students well so that in the learning process inclusion children and regular children can receive the equal service. The components that need to be considered by the school are the curriculum, teaching staff, and supporting facilities so that students with special needs can experience education with other regular students.

Lack of awareness and understanding of disability is the main problem in creating inclusive education..$^{50}$ The essential step in order to achieve the goal of inclusive education is to develop a positive attitude towards people who are different but equal in rights and obligations, despite the social, economic or educational background..$^{51}$ Inclusive education should be prepared with teachers who have a positive attitude in accepting inclusive students in their classroom. It is essential to build a conducive environment for all students while they are studying together. Moreover, Maria explained that the positive attitude can be made especially in an educational context, with the help of teachers. ${ }^{52}$ In this case, a teacher also needs to give adequate information about inclusive education not only to the regular students but also to the students' parents to make them understand the philosophy and the meaning of inclusive education clearly so that they will develop their positive attitude towards students with special needs. ${ }^{53}$

\section{CURRICULUM, TEACHING, AND LEARNING ACTIVITIES}

The curriculum is an essential component in implementing inclusive education. In the inclusive class which consists of regular and students of special 
need who have various learning needs, it is necessary to modify the curriculum, learning strategy, and assessment system. ${ }^{54}$ Regulation of the Minister of National Education Number 70 of 2009 article 7 states that education units administering inclusive education use an education unit level curriculum that accommodates the needs and abilities of students according to their talents and requests. ${ }^{55}$ The education unit of curriculum level is an operational curriculum compiled by schools with regard to the competency standards and basic competencies that have been developed by the National Education Standards Agency (BNSP). This curriculum is specially prepared by schools with regard to the characteristics and conditions of their students. With the education unit curriculum, schools have the authority to modify the curriculum according to their individual needs, but this is still based on competency standards and basic competencies established by BNSP.

Only one school out of the four elementary schools in this research that modified the curriculum to facilitate inclusion students. The other three elementary schools conducted the learning process in accordance with the government-determined curriculum, namely the 2013 Curriculum. Elementary School (D) modified the curriculum by expanding Indicators of Competency Achievement (IPK) students. IPK is one of the pivotal components in a Learning Implementation Plan (RPP). The IPK shows an indicator that the competencies learned have been fully mastered by students and are formulations of abilities that should be performed or displayed by students to show the achievement of Basic Competencies (KD). The IPK formulation uses a specific and measurable operational verb. IPK measures 3 components: students' knowledge, attitudes, and skills. Expanding the IPK in the curriculum is very useful for inclusion classes to facilitate the learning process of each student according to their respective levels of ability. It is possible to lower the basic competencies to master by the students with special needs than that of regular students, so the IPK should be adapted to the abilities and needs of these students.

In the daily learning process in the classroom, the four Elementary schools use the Regular class with Cluster models. Regular class with clusters models place students with special needs in regular classes together with other regular students, but students with special needs are placed in special groups..$^{56}$ This model is applied by Elementary School (C, D). Students with special needs sit in an area that is easily accessible by the teacher to ease the teacher in supervising and providing direction during the classroom learning process. 


\section{EDUCATIONAL STAFFS}

In this study, only 1 school has a shadow teacher, that is Elementary School (D). Shadow teacher is the teacher who helps students with special needs in the teaching and learning process in the classroom. In carrying out their duties in the classroom, the shadow teacher collaborates with regular classroom teachers who teach regular students.

Regulation of the Minister of National Education Number 70 of 2009 article 10 number 3 states that the district or city government is required to improve competence in the field of special education for educators and education personnel in education units providing inclusive education. ${ }^{57}$ Teacher training systems need to mainstream the skills and knowledge of inclusive education to improve knowledge of regular classroom teachers in the implementation of inclusive classes. ${ }^{58}$ However, in this study, none of all elementary schools received a training program held by the government. Elementary School (D) has conducted a training program for all regular classroom teachers to study the implementation of inclusive learning in the classroom every semester independently. This step is carried out to increase the competence of regular class teachers in helping students with special needs to follow the learning process at school. Research by De Bjoer, Pijl, and Minnaert states that teachers who had attended training in the implementation of inclusive schools or special education have a more positive attitude towards inclusive education compared to teachers who do not receive any training at all. ${ }^{59}$ Teachers with shorter teaching experience have more positive attitudes towards inclusive students, especially students with special needs than teachers who have longer teaching experience. ${ }^{60}$

One of the competencies that teachers need to have in dealing with students, both regular students, and special needs are teachers who are able to conduct assessments and are able to communicate well with colleagues, as well as parents of students. There are three strategies that prioritized communication with students which were inclusive in nature. These are: teachers give feedback and paying sustained and inclusive attention to all students; teachers create an environment where students feel safe, and teachers draw on students' backgrounds in their pedagogic discourse. ${ }^{61}$ The results of the observation indicate that elementary school teachers $(C)$ provide an assessment to students with special needs in two ways. The first way is to approach students, such as by way of inviting students to have a private talk in their spare time, giving advice not to break the rules, and inviting students to be 
involved in classroom learning. Such personal approach aims to make students feel safe and comfortable in the school environment. The teacher also communicates with fellow teachers who handle students with special needs and parents of students with special needs regarding student development. Second, teachers spare special time to students with special needs in understanding the learning materials and arranging their seats in front of the teacher to enable teachers to monitor the students' progress constantly.

In addition to teacher competence, teacher attitudes are also very essential in dealing with special needs children. Teachers should understand students with various characteristics. ${ }^{62}$ It is vital that teachers should develop new ways of believing and acknowledging that all children can learn, all children are worth educating, and they have the capacity to make a difference to children's lives. Such work is their responsibility. ${ }^{63}$ Elementary school teacher (C) states that one of the keys to deal with children with special needs is patience. The teacher also should believe that special need students can work on their learning task based on their ability and teachers should convince the students that they are able to work on their school task by themselves. In the end, teachers and the regular students celebrate the completion that has been made by the special need student; such celebration aims to develop the confidence of the special need student.

In carrying out the learning process in inclusive classrooms, teachers cannot work alone. Teamwork and collaboration are very relevant for all teachers or staff in an inclusive school. ${ }^{64}$ In the school's internal environment, there should be a collaboration between the school principal, teachers and employees. The school should also collaborate with external parties by enabling teachers and staff to work with parents and other parties such as the government, special education institutions, community health centres, and nongovernmental organizations.

The Principal of the Elementary School (A, B) said that teachers required a background in Special Education to teach students with special needs. At present, this school does not have a teacher with special education background so it does not accept students with special needs to study there. In addition, according to the Principal of Elementary School (B) in terms of human resources, teachers have not been able to optimally provide support for regular students so that services and support for children with special needs would not be optimal. This is contrary to the results of observations in Elementary School (C). In terms of education staff, Elementary School (C) 
proved that regular class teachers who are not from a Special Education background, but who have initiative, knowledge, and good attitude would be able to conduct learning in an inclusive setting even though the school does not have complete facilities and infrastructure for the implementation of inclusive schools.

\section{FACILITIES, INFRASTRUCTURE, AND FUNDING}

Complete facilities are one of the supporting factors for the success of a program, including in the implementation of inclusive schools. ${ }^{65}$ The Principal of the Elementary School (C) states that it needed complete and adequate facilities to carry out inclusive education in schools. The current facilities are considered to be inadequate to provide services for students with special needs. Elementary School (A) states the same thing that inclusive schools need more comprehensive facilities than regular schools.

The other two elementary schools claim that an inclusive school would only be realized if the government provided them with sufficient funding. Financing is closely related to the adequacy of the implementation of a program. ${ }^{66}$ The Principal of the Elementary School (B) stated that financing was the most-valuable factor because sufficient funds would allow them to employ a teacher with special need education background to school and provide adequate facilities for students with special needs. The Principal of the Elementary School (B) explained that the school frequently obtained students with special needs and found it difficult to facilitate these students in teaching and learning activities. This is due to the lack of facilities and infrastructure for the learning of inclusive children. The school decides to suggest parents to transfer their children to an inclusive school as recommended and appointed by the government. The Principal of the Elementary School (B) stated that this decision was made to develop the overall learning system in the Elementary School (B) and to allow students with special needs to learn in places that have the supporting facilities and required infrastructure.

Elementary School (A, C, D) also stated that funding is a beneficial factor to provide facilities for students with special needs, for example by providing textbooks with braille for blind students, and by providing school facilities for students with physical disorders. Elementary School (D) is a regular school that accepts students with special needs. However, due to inadequate facilities, the school only accepts students with special needs in the category of mental retardation, Attention Deficit Hyperactivity Disorder (ADHD), moder- 
ate mental retardation, low vision, and a slow learner. Furthermore, Elementary School (C), stated that the school is a regular school with regular facilities. However, they accept special needs students, such as slow learner students.

\section{RELATIONSHIP BETWEEN COMMUNITY AND SCHOOL}

Teamwork and collaboration are very relevant for all teachers or staff in an inclusive school. ${ }^{67}$ Regulation of the Minister of National Education Number 70 of 2009 article 11 number 1 states that education units administering inclusive education have the right to obtain professional assistance from district or city governments as needed. ${ }^{68}$

\section{ENDNOTES}

1 Patricia J. Bonner, Susan R. Warren, and Ying H. Jiang, "Voices From Urban Classrooms: Teachers' Perceptions on Instructing Diverse Students and Using Culturally Responsive Teaching," Education and Urban Society 50, no. 8 (November 15, 2018): 697-726, https://doi.org/10.1177/0013124517713820.

2 UNESCO, The Salamanca Framework, issued 1994.

3 UNESCO. The Salamanca Framework, issued 1994.

4 S B Wibowo and J A Muin, "Inclusive Education in Indonesia: Equality Education Access for Disabilities,” KnE Social Sciences 3, no. 5 (2018): 484, https:// doi.org/10.18502/kss.v3i5.2351.

5 Suguru Mizunoya, Sophie Mitra, and Izumi Yamasaki, "Disability and School Attendance in 15 Low- and Middle-Income Countries," World Development 104 (2018): 388-403, https://doi.org/10.1016/j.worlddev.2017.12.001.

6 MPNR Indonesia, PPTN Di Lingkungan Luar Biasa (SDLB, and undefined 2008, "Peraturan Menteri Pendidikan Nasional Republik Indonesia," Library.Binus.Ac.Id, accessed March 1, 2021, http://library.binus.ac.id/ecolls/ eBook/DaftarIsi/isi_1009084.pdf.

7 UNESCO, The Salamanca Framework, issued 1994.

8 Indonesia, ..., and 2008, "Peraturan Menteri Pendidikan Nasional Republik Indonesia."

9 Ediyanto Ediyanto et al., "The Education and Training Program Guideline for Special Guidance Teacher Competence Development in Indonesia Inclusive School," IJDS: Indonesian Journal of Disabilities Studies 5, no. 2 (2018): 251-67.

10 Sofwan Adiputra, "Perceptions of Inclusion Education by Parents of Elementary School-Aged Children in Lampung, Indonesia.," International Journal of Instruction 12, no. 1 (2019): 199-212.

11 Amarina Ashar Ariyanto et al., Diversity in Unity: Perspectives from Psychology and Behavioral Sciences (CRC Press, 2017).

12 “Cambridge Dictionary," 2019. 
13 Sylvine Schmidt and Michèle Venet, "Principals Facing Inclusive Schooling or Integration," Canadian Journal of Education 35, no. 1 (2012): 217-38.

14 Ömür Sadioglu et al., "Problems, Expectations, and Suggestions of Elementary Teachers Regarding Inclusion," Educational Sciences: Theory $\mathcal{E}$ Practice 13, no. 3 (2013): 1760-65, https://doi.org/10.12738/estp.2013.3.1546.

15 Indonesia, ..., and 2008, "Peraturan Menteri Pendidikan Nasional Republik Indonesia."

16 Indah Permata Darma and Binahayati Rusyidi, "Pelaksanaan Sekolah Inklusi Di Indonesia," in Prosiding KS:Riset EF PKM, vol. 2, 2003, 223-27.

17 Y. Wahyuni, "Identifikasi Gaya Belajar ( Visual, Auditorial, Universitas Bung Hatta” 10, no. 2 (2017): 128-32.

18 Annette Vincent and Dianne Ross, "Learning Style Awareness A Basis For Developing Teaching and Learning Strategies," Eflpresentations.Pbworks.Com, accessed March 1, 2021, http://eflpresentations.pbworks.com/f/ Good+summary+of+learning+style+models.pdf.

19 John D Mayer, "Asserting the Definition of Personality," 2007, 1-4.

20 S. A Mu'min, "Variasi Individual Dalam Pembelajaran," Al-Ta'dib 7, no. 1 (2014): 68-83.

21 Joane Nagel, "Constructing Ethnicity/: Creating and Recreating Ethnic Identity and Culture Constructing Ethnicity/: Creating and Recreating Ethnic Identity and Culture," Social Problems 41, no. 1 (2009): 152-76.

22 “Cambridge Dictionary." ISBN: 9780521152532. April, 2013

23 "Cambridge Dictionary." ISBN: 9780521152532. April, 2013

24 Elizabeth H Baker, "Definition of Socioeconomics Status," in The Wiley Blackwell Encyclopedia of Health, Illness, Behavior, and Society, 2014.

25 Baker, Elizabeth H. "Definition of Socioeconomics Status." In The Wiley Blackwell Encyclopedia of Health, Illness, Behavior, and Society, 1-5, 2014

26 Abdul Mukti, Ahsan Somadlon, and Alexander Thomas Hauschild, Merangkul Perbedaan: Perangkat Untuk Mengembangkan Lingkungan Inklusif, Ramah Terhadap Pembelajaran, Edisi Keem (Bangkok: UNESCO-Biro Regional Asia dan Pasifik untuk Pendidikan, 2007).

27 Alison Buckler, "Teachers' Professional Capabilities and the Pursuit of Quality in Sub-Saharan African Education Systems: Demonstrating and Debating a Method of Capability Selection and Analysis," Journal of Human Development and Capabilities 17, no. 2 (2016): 161-77, https://doi.org/10.1080/ 19452829.2014.991706.

28 Buckler, Alison. “Teachers' Professional Capabilities and the Pursuit of Quality in Sub-Saharan African Education Systems: Demonstrating and Debating a Method of Capability Selection and Analysis." Journal of Human Development and Capabilities 17, no. 2 (2016): 161-77. https://doi.org/10.1080/ 19452829.2014 .991706$.

29 Mukti, Somadlon, and Hauschild, Merangkul Perbedaan: Perangkat Untuk Mengembangkan Lingkungan Inklusif, Ramah Terhadap Pembelajaran. 2016

30 Indonesia, ..., and 2008, "Peraturan Menteri Pendidikan Nasional Republik 
Indonesia."

31 Mizunoya, Mitra, and Yamasaki, "Disability and School Attendance in 15 Lowand Middle-Income Countries.” World Development 104 (2018): 388-403. https:/ /doi.org/10.1016/j.worlddev.2017.12.001.

32 Admila Rosada, Menjadi Guru Kreatif: Praktik-Praktik Pembelajaran Di Sekolah Inklusif(Yogyakarta: Kanisius, 2018).

33 Fawzia A. Hadis, "Toward Inclusive Inclusive Education in Indonesia a Country Report By/: Prof DR. Fawzia Aswin Hadis Presented at Seisa University, Ashibetsu-Shi Hokkaido Japan July $9 £ 2005 ”$ (Hokkaido, 2005).

34 Iva Nandya Atika, Norimune Kawai, and Edy Prabowo, "Inclusive Education In Indonesia From The Perspective Of Widyaiswara In Centre For Development And Empowerment Of Teachers And Education Personnel Of Kindergartens," And Special Education Indonesian Journal of Disability Studies (IJDS, 2017, http://ijds.ub.ac.id/.

35 Goffman Erving, Stigma: Notes on The Management of Spoiled Identity (London: Penguin Books, 1963).

36 Reza Dulisanti, "Penerimaan Sosial Dalam Proses Pendidikan Inklusif (Studi Kasus Pada Proses Pendidikan Inklusif Di Smk Negeri 2 Malang)," Indonesian Journal of Disability Studies (IJDS) 2, no. 1 (2015): 52-60.

37 Taruri Dewi Aniska, "Layanan Anak Berkebutuhan Khusus Di Sekolah Penyelenggara Pendidikan Inklusif (SPPI) Sekolah Dasar Wilayah Kecamatan Lendah Kabupaten Kulon Progo,” no. 1 (2016): 1.

38 "Data Amal Usaha Muhammadiyah," n.d.

39 Dinas Pendidikan Pemuda dan Olahraga Provinsi DIY, "Penetapan Sekolah Inklusi Provinsi Daerah Istimewa Yogyakarta” (2016).

40 Fauzi Ahmad, "Pendidikan Inklusif Berbasis Kearifan Lokal Dalam Praktik Sosial Di Pesantren Zainul Hasan Genggong Probolinggo Jawa Timur," Proceedings Ancoms 1St Annual Conference For Muslim Scholars 2, no. 110 (2017): 715-25.

${ }^{41}$ John W. Creswell, Research Design Qualitative, Quantitaive, and Mixed Methods Approaches, Sage, Third Edit (Los Angeles: SAGE Publications Sage CA: Los Angeles, CA, 2009), https://doi.org/10.2307/1523157.

42 John W. Creswell and David J Creswell, Research Design Qualitative, Quantitative, and Mixed Methods Approaches, Fifth Edit, vol. 5 (Los Angeles: Sage, 2018).

43 Matthew B Miles, Michael A Huberman, and Johnny Saldana, Qualitative Data Analysis: A Methods Sourcebook, Sage, Third Edit, vol. 5 (California: Sage Publication, 2014).

44 N Carter et al., "The Use of Triangulation in Qualitative Research.," 2012, https://doi.org/10.1188/14.ONF.545-547.

45 Uwe Flick, "Triangulation in Data Collection," in The SAGE Handbook of Qualitative Data Collection, ed. Uwe Flick (London: Sage Publication, 2018), 527-44, https://doi.org/10.1007/978-3-319-54672-8_15.

46 Mel Ainscow and Abha Sandill, "Developing Inclusive Education Systems: The Role of Organisational Cultures and Leadership," International Journal of Inclusive Education 14, no. 4 (June 2010): 401-16, https://doi.org/10.1080/ 
13603110802504903.

47 UNESCO, The Salamanca Framework, issued 1994.

48 UNESCO. The Salamanca framework, issued 1994

49 Sadioglu et al., "Problems, Expectations,and Suggestions of Elementary Teachers Regarding Inclusion." 2013.

50 By Marion Steff, Ro Mudzakir, and M Andayani, "Equity and Access to Tertiary Education for Students with Disabilities in Indonesia," 2010, 1-30.

51 Unianu Ecaterina Maria, "Teachers' Perception, Knowledge and Behaviour in Inclusive Education," Procedia - Social and Behavioral Sciences 84 (July 2013): 1237-41, https://doi.org/10.1016/j.sbspro.2013.06.736.

52 Maria, Unianu, Ecaterina. "Teachers' Perception, Knowledge and Behaviour in Inclusive Education." Procedia - Social and Behavioral Sciences 84 (July 2013): 1237-41. https://doi.org/10.1016/j.sbspro.2013.06.736.

53 Adiputra, "Perceptions of Inclusion Education by Parents of Elementary SchoolAged Children in Lampung, Indonesia." 2019

54 Sri Widiastuti et al., "Evaluation of the Implementation of the Educational Inclusion of Junior High School Level in Central Java Constructs," Journal of Social Science Studies 4, no. 2 (February 6, 2017): 1, https://doi.org/10.5296/ jsss.v4i2.10694.

55 Indonesia, ..., and 2008, "Peraturan Menteri Pendidikan Nasional Republik Indonesia."

56 Darma and Rusyidi, "Pelaksanaan Sekolah Inklusi Di Indonesia”. 2015

57 Indonesia, ..., and 2008, "Peraturan Menteri Pendidikan Nasional Republik Indonesia."

58 Mizunoya, Mitra, and Yamasaki, "Disability and School Attendance in 15 Lowand Middle-Income Countries." 2018

59 Pennee Kantavong et al., "A Comparative Study of Teacher's Opinions Relating to Inclusive Classrooms in Indonesia and Thailand," Kasetsart Journal of Social Sciences 38, no. 3 (September 1, 2017): 291-96, https://doi.org/10.1016/ j.kjss.2016.05.005.

60 Kantavong, Pennee, Sujarwanto, Suwaree Rerkjaree, and Budiyanto. "A Comparative Study of Teacher's Opinions Relating to Inclusive Classrooms in Indonesia and Thailand." Kasetsart Journal of Social Sciences 38, no. 3 (September 1, 2017): 291-96.

61 Buckler, "Teachers' Professional Capabilities and the Pursuit of Quality in SubSaharan African Education Systems: Demonstrating and Debating a Method of Capability Selection and Analysis." 2016

62 Anita Aisah and Dwi AB Santosa, "Islamic Education in The Inclusive School: Experimental Study of The Application of Differentiated Instruction For Slow Learners," Host-Pustaka.Umy.Ac.Id 15, no. 2 (2019), https://doi.org/10.18196/ AIIJIS.2019.0106.281-301.

63 Zalizan Mohd Jelas, "Learner Diversity and Inclusive Education: A New Paradigm for Teacher Education in Malaysia," Procedia - Social and Behavioral Sciences 7 (2010): 201-4, https://doi.org/10.1016/j.sbspro.2010.10.028. 
64 Elizabeth O'Gorman and Sheelagh Drudy, “Addressing the Professional Development Needs of Teachers Working in the Area of Special Education/Inclusion in Mainstream Schools in Ireland," Journal of Research in Special Educational Needs 10, no. SUPPL. 1 (2010): 157-67, https://doi.org/10.1111/j.14713802.2010.01161.x.

65 Widiastuti et al., "Evaluation of the Implementation of the Educational Inclusion of Junior High School Level in Central Java Constructs.” 2015

66 Widiastuti et al. Widiastuti et al., "Evaluation of the Implementation of the Educational Inclusion of Junior High School Level in Central Java Constructs." 2015

67 O'Gorman and Drudy, "Addressing the Professional Development Needs of Teachers Working in the Area of Special Education/Inclusion in Mainstream Schools in Ireland." 2020

68 Indonesia, ..., and 2008, "Peraturan Menteri Pendidikan Nasional Republik Indonesia."

\section{REFFERENCE}

Adiputra, Sofwan. "Perceptions of Inclusion Education by Parents of Elementary School-Aged Children in Lampung, Indonesia." International Journal of Instruction 12, no. 1 (2019): 199-212.

Ahmad, Fauzi. "Pendidikan Inklusif Berbasis Kearifan Lokal Dalam Praktik Sosial Di Pesantren Zainul Hasan Genggong Probolinggo Jawa Timur.” Proceedings Ancoms 1St Annual Conference For Muslim Scholars 2, no. 110 (2017): 715-25.

Ainscow, Mel, and Abha Sandill. "Developing Inclusive Education Systems: The Role of Organisational Cultures and Leadership." International Journal of Inclusive Education 14, no. 4 (June 2010): 401-16. https://doi.org/10.1080/ 13603110802504903.

Aisah, Anita, and Dwi AB Santosa. "Islamic Education in The Inclusive School: Experimental Study of The Application of Differentiated Instruction For Slow Learners." Host-Pustaka.Umy.Ac.Id 15, no. 2 (2019). https://doi.org/10.18196/ AIIJIS.2019.0106.281-301.

Aniska, Taruri Dewi. "Layanan Anak Berkebutuhan Khusus Di Sekolah Penyelenggara Pendidikan Inklusif (SPPI) Sekolah Dasar Wilayah Kecamatan Lendah Kabupaten Kulon Progo,” no. 1 (2016): 1.

Ariyanto, Amarina Ashar, Hamdi Muluk, Peter Newcombe, Fred P Piercy, E Kristi Poerwandari, and Sri Hartati R Suradijono. Diversity in Unity: Perspectives from Psychology and Behavioral Sciences. CRC Press, 2017.

Baker, Elizabeth H. "Definition of Socioeconomics Status." In The Wiley Blackwell Encyclopedia of Health, Illness, Behavior, and Society, 1-5, 2014.

Bonner, Patricia J., Susan R. Warren, and Ying H. Jiang. "Voices From Urban

Classrooms: Teachers' Perceptions on Instructing Diverse Students and Using Culturally Responsive Teaching." Education and Urban Society 50, no. 8 (November 15, 2018): 697-726. https://doi.org/10.1177/0013124517713820.

Buckler, Alison. “Teachers' Professional Capabilities and the Pursuit of Quality in 
Sub-Saharan African Education Systems: Demonstrating and Debating a Method of Capability Selection and Analysis." Journal of Human Development and Capabilities 17, no. 2 (2016): 161-77. https://doi.org/10.1080/ 19452829.2014 .991706$.

“Cambridge Dictionary," 2019.

Carter, N, D Bryant-Lukosius, A DiCenso, J Blythe, and AJ Neville. "The Use of Triangulation in Qualitative Research.,” 2012. https://doi.org/10.1188/ 14.ONF.545-547.

Creswell, John W. Research Design Qualitative, Quantitaive, and Mixed Methods Approaches. Sage. Third Edit. Los Angeles: SAGE Publications Sage CA: Los Angeles, CA, 2009. https://doi.org/10.2307/1523157.

Creswell, John W., and David J Creswell. Research Design Qualitative, Quantitative, and Mixed Methods Approaches. Fifth Edit. Vol. 5. Los Angeles: Sage, 2018.

Darma, Indah Permata, and Binahayati Rusyidi. "Pelaksanaan Sekolah Inklusi Di Indonesia.” In Prosiding KS:Riset Eु PKM, 2:223-27, 2003.

"Data Amal Usaha Muhammadiyah," n.d.

DIY, Dinas Pendidikan Pemuda dan Olahraga Provinsi. Penetapan Sekolah Inklusi Provinsi Daerah Istimewa Yogyakarta (2016).

Dulisanti, Reza. "Penerimaan Sosial Dalam Proses Pendidikan Inklusif (Studi Kasus Pada Proses Pendidikan Inklusif Di Smk Negeri 2 Malang)." Indonesian Joumal of Disability Studies (IJDS) 2, no. 1 (2015): 52-60.

Ediyanto, Ediyanto, Agus Mulyadi, Agus Supriatna, and Norimune Kawai. "The Education and Training Program Guideline for Special Guidance Teacher Competence Development in Indonesia Inclusive School." IJDS: Indonesian Journal of Dissability Studies 5, no. 2 (2018): 251-67.

Erving, Goffman. Stigma: Notes on The Management of Spoiled Identity. London: Penguin Books, 1963.

Flick, Uwe. “Triangulation in Data Collection.” In The SAGE Handbook of Qualitative Data Collection, edited by Uwe Flick, 527-44. London: Sage Publication, 2018. https://doi.org/10.1007/978-3-319-54672-8_15.

Hadis, Fawzia A. “Toward Inclusive • C Inclusive Education in Indonesia a Country Report By/: Prof DR. Fawzia Aswin Hadis Presented at Seisa University, Ashibetsu-Shi Hokkaido Japan July $9 £$ 2005.” Hokkaido, 2005.

Indonesia, MPNR, PPTN di Lingkungan Luar Biasa (SDLB, and undefined 2008. "Peraturan Menteri Pendidikan Nasional Republik Indonesia." Library.Binus.Ac.Id.Accessed March 1, 2021. http://library.binus.ac.id/ecolls/ eBook/DaftarIsi/isi_1009084.pdf.

Jelas, Zalizan Mohd. "Learner Diversity and Inclusive Education: A New Paradigm for Teacher Education in Malaysia." Procedia-Social and Behavioral Sciences 7 (2010): 201-4. https://doi.org/10.1016/j.sbspro.2010.10.028.

Kantavong, Pennee, Sujarwanto, Suwaree Rerkjaree, and Budiyanto. "A Comparative Study of Teacher's Opinions Relating to Inclusive Classrooms in Indonesia and Thailand." Kasetsart Journal of Social Sciences 38, no. 3 (September 1, 2017): 291-96. https://doi.org/10.1016/j.kjss.2016.05.005. 
Maria, Unianu Ecaterina. “Teachers' Perception, Knowledge and Behaviour in Inclusive Education.” Procedia - Social and Behavioral Sciences 84 (July 2013): 123741. https://doi.org/10.1016/j.sbspro.2013.06.736.

Mayer, John D. "Asserting the Definition of Personality," 2007, 1-4.

Miles, Matthew B, Michael A Huberman, and Johnny Saldana. Qualitative Data Analysis: A Methods Sourcebook. Sage. Third Edit. Vol. 5. California: Sage Publication, 2014.

Mizunoya, Suguru, Sophie Mitra, and Izumi Yamasaki. "Disability and School Attendance in 15 Low- and Middle-Income Countries." World Development 104 (2018): 388-403. https://doi.org/10.1016/j.worlddev.2017.12.001.

Mu'min, S. A. "Variasi Individual Dalam Pembelajaran." Al-Ta'dib 7, no. 1 (2014): 68-83.

Mukti, Abdul, Ahsan Somadlon, and Alexander Thomas Hauschild. Merangkul Perbedaan: Perangkat Untuk Mengembangkan Lingkungan Inklusif, Ramah Terhadap Pembelajaran. Edisi Keem. Bangkok: UNESCO-Biro Regional Asia dan Pasifik untuk Pendidikan, 2007.

Nagel, Joane. "Constructing Ethnicity/: Creating and Recreating Ethnic Identity and Culture Constructing Ethnicity/: Creating and Recreating Ethnic Identity and Culture *." Social Problems 41, no. 1 (2009): 152-76.

Nandya Atika, Iva, Norimune Kawai, and Edy Prabowo. "Inclusive Education In Indonesia From The Perspective Of Widyaiswara In Centre For Development And Empowerment Of Teachers And Education Personnel Of Kindergartens.” And Special Education Indonesian Journal of Disability Studies (IJDS, 2017. http:// ijds.ub.ac.id/.

O'Gorman, Elizabeth, and Sheelagh Drudy. "Addressing the Professional Development Needs of Teachers Working in the Area of Special Education/Inclusion in Mainstream Schools in Ireland." Journal of Research in Special Educational Needs 10, no. SUPPL. 1 (2010): 157-67. https://doi.org/10.1111/j.14713802.2010.01161.x.

Rosada, Admila. Menjadi Guru Kreatif: Praktik-Praktik Pembelajaran Di Sekolah Inklusif. Yogyakarta: Kanisius, 2018.

Sadioglu, Ömür, Asude Bilgin, Sema Batu, and Aynur Oksal. "Problems, Expectations, and Suggestions of Elementary Teachers Regarding Inclusion." Educational Sciences: Theory $\mathcal{G}$ Practice 13, no. 3 (2013): 1760-65. https:// doi.org/10.12738/estp.2013.3.1546.

Schmidt, Sylvine, and Michèle Venet. "Principals Facing Inclusive Schooling or Integration.” Canadian Journal of Education 35, no. 1 (2012): 217-38.

Steff, By Marion, Ro Mudzakir, and M Andayani. "Equity and Access to Tertiary Education for Students with Disabilities in Indonesia,” 2010, 1-30.

UNESCO. The Salamanca Statement Framework, issued 1994.

Vincent, Annette, and Dianne Ross. "Learning Style Awareness A Basis For Developing Teaching and Learning Strategies." Eflpresentations.Pbworks.Com. Accessed March 1, 2021. http://eflpresentations.pbworks.com/f/Good+summary+of+learning+style+models.pdf. 
Wahyuni, Y. "Identifikasi Gaya Belajar ( Visual, Auditorial, Universitas Bung Hatta” 10, no. 2 (2017): 128-32.

Wibowo, S B, and J A Muin. "Inclusive Education in Indonesia: Equality Education Access for Disabilities.” KnE Social Sciences 3, no. 5 (2018): 484. https:// doi.org/10.18502/kss.v3i5.2351.

Widiastuti, Sri, Sri Suwitri, Y. Warella, and. Haryono. "Evaluation of the Implementation of the Educational Inclusion of Junior High School Level in Central Java Constructs." Journal of Social Science Studies 4, no. 2 (February 6, 2017): 1. https://doi.org/10.5296/jsss.v4i2.10694. 